\title{
EDUCATIONAL ACTIVITIES OF CLERGY IN RUSSIA
}

\author{
Svetlana Solovieva ${ }^{1}$, Elena Savitskaite ${ }^{2}$, Anna Makarova $^{3}$, Nina Cheryomuhina ${ }^{4}$ \\ ${ }^{1}$ Senior Lecturer, Voronezh State Technical University, 20 years of October Street, 84, Voronezh, \\ Russia, E-mail: d18sveta@mail.ru \\ ${ }^{2}$ Candidate of Philological Sciences, Associate Professor, Voronezh State Technical University, 20 \\ years of October Street, 84, Voronezh, Russia, E-mail: eleonor19sa@mail.ru \\ ${ }^{3}$ Candidate of Philological Sciences, Associate Professor, Voronezh State Technical University, 20 \\ years of October Street, 84, Voronezh, Russia, E-mail: annasaborowskaja2017@mail.ru \\ ${ }^{4}$ Senior Lecturer, Voronezh State Technical University, 20 years of October Street, 84, Voronezh, \\ Russia, E-mail: cheremuhinevg@gmail.com
}

\begin{abstract}
The article discusses the educational transformation of Russian society, which has significantly updated the question of the role of the Orthodox Church and Orthodox values in the spiritual life of society. The study of church activities in the field of solving socially significant problems, including the tasks of religious and moral education of Russians, in difficult conditions of political destabilization and disintegration, during the crisis of power and social maneuvering by power structures, is an important factor in the historical restructuring of the socio-cultural spaces of pre-revolutionary Russia. In close connection with the all-Russian processes of social, political and cultural development, this article analyzes the issues of the influence of the Russian Orthodox Church on the spiritual life of the Russian population.
\end{abstract}

Keywords: church, education, society, state, power.

\section{INTRODUCTION}

The relevance of the study is due to the modern revival of Orthodox spirituality and parish life, a revision of the status of religious values in modern Russian public consciousness. In the context of the intensification of Orthodox construction, the expanding role of the Orthodox Church in society, historians increasingly turn to the problems of the historical development of the Russian Church, continue to search for answers to complex questions about the place and role of Orthodoxy, its axiological system in the process of formation and development of Russian spiritual culture.

Increasingly, society raises questions about the participation of the clergy in the development of moral guidelines for Russians. The rich historical experience of the Church in resolving the problems of the religious and moral development of society, the wide practice of interacting with the Orthodox and nonOrthodox populations, are thus becoming more and more relevant today. It is not by chance that researchers 
are interested in the most difficult periods in the life of the Orthodox Church, in particular, the period of bourgeois transformation of Russian society and the state.

\section{METHODOLOGY}

The methodological basis of the study is the fundamental principles of historical science - systemicity, scientific objectivity, determinism and historicism, which allow us to represent historical phenomena in the process of their development in the context of general historical conditions, to show the close interconnections of phenomena and historical facts.

In the work, a modernization theoretical and methodological approach was used, according to which the processes of the spiritual development of society, as well as measures to form piety in dioceses, are considered in the context of the incomplete transition of Russian society from the traditional to the industrial stage. The church's participation in the spiritual life of the population within the framework of this approach appears to be closely related to the value disorientation of Russian society. In accordance with the theory of modernization, special attention is paid to the factor of state policy in the field of the formation of value guidelines on the basis of Orthodoxy.

\section{DISCUSSION}

The historiographic review is presented by studies that analyze the historical and pedagogical process as an integral part of the country's historical and cultural development (V.G. Bezrogov, L.N. Belenchuk, A.Yu. Butov, A.V. Ovchinnikov, V.Yu. Troitsky and other); works on the problems of Orthodox anthropology and spiritual education (V.V. Zenkovsky, S.Yu. Divnogortseva, E.A. Plekhanov, T.V. Sklyarova and others); ideas of Russian Orthodox pedagogy (V.V. Zenkovsky, I.A. Ilyin, A.V. Kuraev, A.E. Likhachev, etc.); ideas of the participation of the Russian Orthodox Church in the education and upbringing of the younger generation (N.M. Belykh, N.D. Nikandrov, S.A. Rachinsky, O. B. Shelygin and others), including the non-Russian peoples of Russia (I. A. Iznoskov, N.I. Ilminsky, K.P. Pobedonostsev, etc.); nationalities in training and education (G.N. Volkov, P.F. Kapterev, S.T. Shatsky, etc.), the Russian national school (E.P. Belozertsev, I.F. Goncharov, K.D. Ushinsky and etc.), the educational impact of folk culture (N.S. Aleksandrova, N.A. Knyazev, N.S. Shiryaev, etc.).

\section{RESULTS}

The analysis of the research results allowed us to draw conclusions that in Russia the formation of the educational activity of the Orthodox Church within the educational system took place in an organic relationship with the economic, socio-cultural development of public life and the country as a whole. In this regard, understanding the historical experience of the Orthodox Church and identifying its role and place in the socio-cultural space of the country and regions in the light of the cardinal transformations of modern Russian society and its educational system is very relevant.

The study identified socio-historical, socio-cultural and pedagogical prerequisites that determined the development of educational activities of the Orthodox Church in the second half of the XIX - early XX century: the annexation of Crimea to Russia, the Crimean war, the Russian-Turkish war, the abolition of serfdom, the implementation of the policy of Russification; strengthening the position of Islam; the influence of foreign colonists of various faiths; the opening of educational institutions and the growing need for teaching staff for them; official approval of schools, colleges, gymnasiums, seminaries as a mandatory type of educational institutions in the provinces.

We can say that by the 90s of the XIX century in Russia there was and successfully operated a network of parochial public schools of various types. Educational importance was also the practice of establishing parish libraries and the organization of public readings.

Another successful public work of the clergy was the organization of the temperance movement. It resulted in the creation of temperance societies in some parishes of the dioceses and the organization of anti-alcohol propaganda by opening reading rooms and conducting special interviews.

The creation and maintenance of almshouses and shelters was not as common and noticeable as, for example, the opening of schools. At the same time, these necessary and truly "God-pleasing" institutions performed their functions quite successfully. Therefore, in this aspect, the activities of the clergy also played a positive role.

The specifics of the everyday life of the parish clergy was determined by a complex of factors, among which were material security, official duties, and class status. An essential role was played by the position in the 
clergy, as well as the composition and security of the parishioners. In the period under study, in a fairly clear form, one could observe a clear contradiction in the position of the parish clergy. On the one hand, its representatives belonged to the privileged class, but on the other, the real situation in the society of the overwhelming mass of clergy and clergy did not correspond to this status. The contradiction manifested itself in the life support system of the parish clergy.

An important source of subsistence for clergy in rural areas was land, which led to the need to spend time and effort on its processing, so a significant part of the clergy was forced to engage in peasant labor. This forced the clergy to lead a lifestyle that did not differ much from the peasant, obeying the agricultural calendar.

\section{CONCLUSION}

In general, the government supported most of the public initiatives in solving social problems. The church at the same time received some advantages over other public organizations because of its generally recognized loyalty to the autocracy and the existing order.

However, "support" was often limited only to permission to engage in one or another activity, not supported either by law or financially. However, difficulties very often did not stop priests in their desire to actively help their parishioners. At the same time, experience has shown that serious success in any activity could be achieved only through effective interaction with authorities at various levels and other public organizations.

\section{REFERENCE LIST}

Ershov B.A. (2010) The Russian Orthodox Church and secular power in the Voronezh province in the XIX early XX centuries. GOU VPO "Voronezh State Technical University". Voronezh. 167 p. (in Russ).

Ershov B.A. (2010) The system of spiritual education in Voronezh province in the 19th century. Education and Society. №. 5 (64). Pp. 105-108. (in Russ).

Ershov B.A., Fursov V.N. (2018) The Russian Church in the State Mechanism of Russia. Bulletin SocialEconomic and Humanitarian Research. № 1. Pp. 32-37.(in Engl).

Ershov B.A., Perevozchikova L.S., Romanova E.V. (2019) Globalization and Intensification of Spiritual Values in Russia in the Philosophical Aspect. 6th International Conference on Education and Social Sciences Abstracts \& Proceedings. Pp. 208-212. (in Engl).

Ershov B.A., Perevozchikova L.S., Romanova E.V., Ashmarov I.A. (2019) The Concept of Spirituality in Social Philosophy. Smart Innovation, Systems and Technologies. T. 139. Pp. 688-694. (in Engl).

Firsov M. V. (1997) Introduction to the theoretical foundations of social work (historical and conceptual aspect). Moscow-Voronezh. 192 p. (in Russ).

Gusev G. V. (1999) Social pedagogy of the Orthodox Church (on the example of the teetotal movement in the late XIX - early XX century). Pedagogy. №. 3. Pp. 56-57. (in Russ).

Karpova V. V. (2006) Intellectuals on the problem of primary public education at the turn of the XIX-XX centuries. (based on press materials). Political culture of the intelligentsia, its place and role in the life of society. Ivanovo. Pp. 276-278. (in Russ).

Leonov D. E. (2010) Social teaching of the Church on the eve of the revolution of 1905-1907 in Russia. Topical issues of studying spiritual culture. M. Pp. 159-165. (in Russ).

Melnikov V. P., Kholostova V. I. (2001) History of social work in Russia. Marketing. 344 p. (in Russ).

Ososkov A. B. (1982) Primary education in pre-revolutionary Russia (1861-1917). Education. 208 p. (in Russ).

Perevozchikova L.S., Ershov B.A., Ashmarov I.A., Volkova E.A. (2017) Role of Russian Orthodox Church in life of peasants in Russia in XIX-the beginning of the XX-th centuries Bylye Gody. Russian historical journal. №. 43 (1). Pp. 121-128. (in Engl).

Romanova E.V., Perevozchikova L.S., Ershov B.A. (2017) The Lifestyle of the Human Being in the Information Society. 3rd International Conference on Advances in Education and Social Sciences 
Proceedings of ADVED Pp. 950-954. (in Engl).

Rozanov V. V. (1995) Collected works. Around the Church walls. M. Republic. 558 p. (in Russ). (in Russ).

Sinelnikov S. P. (1999) the Russian Orthodox Church and the famine of 1891. Volga. Pp. 58-72. (in Russ).

Talberg N. (2004) History of the Russian Church. Moscow, Sretensky monastery publishing House. 560 p. (in Russ).

Ulyanova G. N. (2005) Legislation on charity in Russia (late XVIII - early XX centuries). National history. №. 6. Pp. 97-98. (in Russ). 